УДК 574

DOI $10.21661 / \mathrm{r}-469952$

В.Г. Кобечинская, Н.А. Аджикелямова, Р.С. Аблаев

СУКЦЕССИОННЫЕ СМЕНЫ СТРУКТУРЫ, БИОМОРФОЛОГИЧЕСКОГО СОСТАВА И ПРОДУКТИВНОСТИ ЛУГОВОЙ РАСТИТЕЛЬНОСТИ ПОЙМЫ РЕКИ ЗУЯ В КРЫМУ

Аннотация: в работе выполнен анализ биоморфологического состава и структуры фитоценозов пробных площадей поймы реки Зуя, который отражает типичные особенности сложения лугов. Выявление изменений в структуре и биоморфологических особенностях растительных сообществ в сравнительном аспекте дают возможность спрогнозировать происходящие в фитоиенозах изменения, а также могут послужить основой для их дальнейшего многолетнего мониторинга.

Ключевые слова: биоморфологическая структура, продуктивность, дигрессия, пасквальная нагрузка, сенокошение, пойменные луга, река Зуя, Крым.

V.G. Kobechinskaya, N.A. Adzhikelyamova, R.S. Ablaev

\title{
SUNGENETIC CHANGES IN THE STRUCTURE, BIOMORPHOLOGICAL COMPOSITION AND PRO-DUCTIVITY OF MEADOW VEGETATION IN THE RIVER ZUYA IN THE CRIMEA
}

Abstract: an analysis of the biomorphological composition and structure of the phytocoenoses of trial plots of the river Zuya, which reflects the typical features of the meadows texture, is represented in the work. Changes identification in the structure and biomorphological features of plant communities in a comparative aspect make it possible to predict the changes occurring in phytocenoses and can also serve as a basis for their further multi-year monitoring.

Keywords: biomorphological structure, productivity, digression, pad load, haymaking, flood meadow, Zuya river, Crimea. 
Исследование ландшафтно-экологических закономерностей состава и структуры растительного покрова является одним из актуальных направлений в современной экологии. Луговые сообщества, являющиеся кормовой базой для сельскохозяйственного производства, как правило, широко представлены в современных ландшафтах. Изучение состава и состояния луговой растительности служит основой для рационального использования сенокосных и пастбищных угодий и предотвращения их от деградации.

Луговые сообщества произрастают в различных почвенно-грунтовых условиях экотопов при постоянном антропогенном воздействии. В условиях сенокошения и выпаса луга, как открытые экосистемы, реагируют на внедрение новых видов, не типичных для зональных условий. Особенно эти процессы проявляются в условиях долинно-террасных комплексов рек, отличающихся разнообразием элементов рельефа.

Основными факторами формирования, существования и развития луговой и лесной прирусловой растительности являются пойменно-аллювиальная деятельность реки, подстилающие породы, хозяйственная деятельность и состояние водосборного бассейна в целом. При взаимодействии этих факторов создаются специфические экологические режимы, определяющие типологический состав лугов и лесов, особенности их размещения и пространственной структуры [1, с. 117]. Для этих экосистем характерна высокая динамичность, обусловленная метеорологическими и гидрологическими условиями, а также различными формами хозяйственной деятельности человека [6, с. 56-67].

Издавна луга используются как кормовые угодья, для рекреации (например, газоны и спортивные площадки), в качестве источника полезных (пищевых, лекарственных и др.), а также кормовых растений, которые можно ввести в культуру или использовать для селекции. Наибольшее значение для народного хозяйства имеет использование лугов как кормовых угодий [2, с. 55]. Поэтому для того, чтобы дать оценку современному их состоянию, а также увидеть направление сукцессионных процессов, учитывая различные формы антропогенного воздействия на данные территории и сообщества в прошлом, нами были заложены 
три пробные площади в типичных пойменных лугах вблизи Балановского водохранилища. Сбор полевого материала и его камеральная обработка проводили согласно общепринятым геоботаническим методикам. Биоморфологические характеристики и ареологический состав видов, слагающих растительный покров яйлы выполнены согласно методике В.Н. Голубева [5, с. 5-71]. Наши исследования ведутся более трех лет с 2015 г. В составе травостоя мы выделили всего 85 видов. Данные по растительности лугов поймы реки Зуя в литературе отсутствуют, поэтому наши исследования носят оригинальный характер и имеют значительный научный интерес

\section{Результатьи исследований}

Наши полевые материалы собирались на правом берегу поймы реки Зуя, вблизи дамбы Балановского водохранилища в Белогорском районе Республики Крым.

Участок №1 - это многолетний сенокос, находится на высоте - 420 м над у. м. В пределах данной площади было выявлено самое высокое флористическое разнообразие - 54 вида, при этом общее проективное покрытие составило 100\%. Средняя высота травостоя в 2015 г. - 20 см. Доминантными видами в 2015 году были: Trifolium medium L., Dactylis glomerata L., Achillea setacea Waldst.etKit., в 2016, 2017 гг. состав доминантных видов не изменился. Здесь была выявлена вязелево-пыреево-тысячелистниково-шалфейная ассоциация.

Участок №2 - контроль, является пойменным лугом, находящимся в среднем течении реки Зуя, 400 м. к северо-востоку от участка №1, расположен на высоте 420 м над у. м. В пределах пробной площади выявлено 49 видов. Общее проективное покрытие составляет - 75-80\%. Средняя высота травостоя - 20,6 см. За годы исследований здесь существенных перестроек не произошло, поэтому выявленные нами в 2015 году доминанты сохранили свои позиции и в последующие годы наблюдений.

Доминантными видами были: Medicago minima,Achillea setaceae. Через 2года доминантный состав не изменился. Субдоминантными являются: Salvia nemorosa, Geranium arvense, Festuca sulcata. 
Здесь была выявлена ассоциация: типчаково-тысячелистниково-шалфейная Ass: Salvia nemorosa-Achillea setaceae- $\{$ Medicago minima $\}$-Festuca sulcata.

Участок №3 - луг с интенсивным выпасом, пробная площадь заложена на первой террасе поймы реки Зуя в 2,5 км. к востоку от с. Баланово на высоте -425 м. над у. м.

Здесь отмечен интенсивный выпас стада лошадей и коров. На учетной площади было обнаружено в 2015 году 38 видов, а через 2 года видовое разнообразие уменьшилось и в 2017 составило всего 24 вида. Общее проективное покрытие в 2015 году было 40-45\%, с годами эти показатели еще снизились и достигли в 2016 - 2017 гг. менее 40\%. Высота травостоя с начала наших наблюдений составляла в среднем 21см.Доминантными видами являются Zerna tinctoria+Convolvulus arvensis. Субдоминантами: Papaver rhoaes, Aegillops cilindrica.

На данной учетной площади была выявлена ковыльно-фиалково-вьюнковоскердовая ассоциация. Ass:Zerna tinctoria+Convolvulus arvensis-Viola citaibeliana $\{$ Papaverrhoaes $\}$ - Stipa capillata.

Период исследований (2015-2017 гг.) по климатическим характеристикам отличался от среднемноголетних показателей, особенно по количеству осадков. Величина их в 2017 г. в сумме составила - 365 мм/год, причем, основная масса их пришлась на весенний период (144 мм). Напротив, в 2015 и 2016 гг. суммарный показатель влагообеспеченности был в существенно выше (487 - 432 мм), причем значительные их объемы пришлись на осенний и зимний периоды (164 - 161 мм). Среднегодовой температурный режим существенно не отличался за отмеченный период - +9,8 - $10,5^{\circ} \mathrm{C}$., но температурные показатели по сезонам имели заметные отличия.

Сравнительный анализ сложения и структуры растительности пробных площадей лугов с учетом разных форм антропогенного воздействия на них вывил следующее. Четко прослеживается закономерность, что в среднем флористическое богатство наиболее значимо на контрольном участке, многолетний сенокос (участок №1) снижает также флористическое разнообразие, но эти показатели колеблются незначительно с 54 видов до 49 видов в 2017 г. преимущественно 
флористический спектр здесь стабилен, т.к. виды адаптировались к ежегодному отчуждению фитомассы и отмечено значительное число видов, обладающих свойством оттавы, т.е. активным наращиванием своей биомассы после сенокошения и вторичным цветением, позволяющим им устойчиво сохранять свои позиции в сообществе, поэтому колебание состава видов в основном за счет случайного внедрения однолетних видов. По остальным участкам этот показатель так же снизился. На контрольном участке (№2) флористическое богатство снижается не значительно (с 49 - до 45 видов). Это обусловлено тем, что мощная подстилка и усиливающаяся мезофитизация территории ведет к выпадению видов, особенно монокарпиков. Главенствуют виды длиннокорневищные и плотнокустовые злаки, вытесняя патиентов и эксплерентов, что ведет к общему снижению флористического разнообразия. Интенсивная нагрузка на пробной площади свидетельствует, как о резком снижении видового разнообразия по годам и значительной упрощении горизонтальной и вертикальной структуры. Здесь самые низкие показатели как высоты травостоя, так и видовой насыщенности на учетных площадках, причем даже с увеличением их размеров с 0,25 м² до 1 м $^{2}$ эти показатели отличаются незначительно $(6,8-7,4)$. Напротив, на контрольной площади четко выявляется линейная зависимость по этим параметрам соответственно с 0,25 м² до $1 \mathrm{~m}^{2}(8,8-10,1)$. Следует отметить, что по этому показателю наивысшие величины выявлены на участке №1 с устойчивым многолетним сенокошением, где отмечены самые высокие показатели (8,4-14,5), т.к. при постоянном отчуждении травостоя создаются условия для внедрения новых видов. Здесь выявлены и самые высокие показатели общего проективного покрытия (95-100\%)с сохранением этих позиций за 3 года наблюдений. Высокий показатель пестроты сложения подтверждает устойчивость данного сообщества, низкий - возможность внедрения новых видов. Самый низкий коэффициент пестроты сложения выявлен на участке №3 -17,3, эту тенденцию подтверждает и коэффициент Жаккара. Самые низкое сходство по флористическому составу между участком №1 и №3 - всего 6\%, т.е. разный режим эксплуатации пробных участком привел к полной перестройке флористического состава данных сообществ и 
формированию обедненного и низкорослого, с значительным выпадением и изреживанием травостоя фитоценоза (общее проективное покрытие здесь менее 40\% в 2017 г). Следует отметить, что коэффициент Жаккара также свидетельствует об очень низком сходстве между участком №1 (сенокошение) и контрольным (участком №2), достигнув всего 34, это говорит о том, что разные формы антропогенного воздействия оказывают очень сильное влияние на сложение и флористический состава лугов, создавая с одной стороны обилие свободных экологических ниш для внедрения новых видов, а с другой, ведя отбор вид

Рассмотрим ареалогическую составляющую по распределению видов на пробных площадях. На контрольном участке ведущими группами являются: палеарктический (Rumex confertus. Medicago falcata), западнопалеарктический (Lollium perenne, Achillea nobilis) ареалы распространения видов, которые вместе достигают почти треть (29\%). На втором месте в убывающем порядке представлены виды голарктического (Convallaria majalis, Plantago major), европейскосредиземноморского, крымского эндемичного (Minuartia taurica, Geranium taurica) и европейско-средиземноморско-переднеазиатского (Medicagominima) в сумме составляя 32\%. Остальные группы имеют незначимые показатели.

На участках №1 и №2 главенствуют группы по значимости использования: кормовые (Poa bulbosa, Carduus acantoides) лекарственные (Achillea nobilis, Melampirum arvense) и медоносные (Trifolium repens, Convolvulus arvense) (44-47\%). Группа ядовитых растений занимает стабильные позиции на участках №1 и №2. Она крайне незначительна, а на участке №3 данная группа полностью отсутствует. Значимость двух важных групп витаминосные и пищевые в структуре фитоценозов крайне незначительна (10-14\%).

Следовательно, значительный спектр представленности хозяйственного использования растений свидетельствует о большом разнообразии видов, формирующих эти сообщества. Таким образом, выявленные механизмы приспособления видов позволяют определить наиболее оптимальные сроки для оценки биологической продуктивности этих сообществ в период максимального развития 
травостоя. Этот период приходится на третью декаду июня, именно в это время и была проведена оценка продуктивности этих сообществ.

Структура и запасы растительного вещества отражают как различия экосистем, так и связи с изменением пространственного размещения на ландшафтном профиле, являясь важнейшими характеристиками растительного покрова. Большие запасы фитомассы указывают на высокую интенсивность продукционного процесса, накопление мортмассы - на низкую скорость деструкции.

Преобладающей группой по продолжительности вегетации всех участков являются летне-зимне-зеленые растения соответственно: 65, 48, 31\%, на участке с многолетним выпасом так же значимой группой являются эфемеры и эфемероиды - 38\%;

По составу основных биоморф на всех участках доминирующее положение занимают поликарпические травы с наибольшим преобладанием на участке с многолетним сенокошением 55\%, на контрольном участке и участке с выпасом эти показатели почти одинаковы, соответственно - 49\% и 50\%;

По структуре и типу корневых систем преобладающее значение в сложении лугов имеют стержнекорневые глубококорневые растения на участках, имеющих разную интенсивность антропогенного воздействия (уч. №1 и №3) - видимо, это один из способов приспособления к воздействию как выпаса, а так и дефициту влаги на протяжении вегетационного периода, роль кистекорневой системы в этих сообществах незначительна;

На всех рассматриваемых пробных площадях количественное распределение растительности по структуре надземных побегов имеет определенную закономерность: более всего представлены полурозеточные растения - 57,54-83\%, причем самые высокие показатели выявлены на участке №3, на втором месте безрозеточная структура надземных побегов - 35-35,17\% и третье место занимают виды с розеточной структурой побегов (8-11,0\%), полностью исчезая на участке с многолетним выпасом;

По способу возобновления на всех участках доминируют симподиальные растения (85-89\%). Высокие показатели симподиальности побегов по способу 
возобновления свидетельствуют об активной весенне-летней генерации побегов. Наличие растений с дихотомическим способом возобновления побегов - незначительно $(5,4-11 \%)$;

По способу приспособлений к вегетативному размножению ведущие позиции на участках №1 и №2 занимают длиннокорневищные (42,37\%) растения - это можно рассматривать, как механизм адаптации видов к интенсивной пасквальной нагрузке в прошлом. Качественно отличаются по анализируемым показателям участок №3. Здесь главенствуют группы плотнокустовых растений и корневых клубней (100\%), полностью угнетая и подавляя остальные группы растений;

По требованию к влаге ведущей группой растений на всех участках являются ксеромезофиты с самыми высокими показателями на участке №3 (67\%).Такие данные свидетельствуют о дефиците влаги, особенно в период вегетации основной массы растений.

Общая продуктивность травостоя пробных площадей поймы реки Зуя в период максимального травостоя за 2016 год довольно высокая, достигая соответственно: 58,0. 52,4 и 31,3 ц/га, причем самые значимые показатели отмечены на участке №1 с многолетним сенокошением. В 2015-2017 годах эти параметры по участкам были в среднем на 30-32\% ниже. Так же следует отметить, что за время исследований самая низкая продуктивность по участкам была отмечена на площади с многолетним выпасом $(26,8 ; 31,3 ; 28$ ц/га)

В связи с ростом температур начинает увеличиваться объем однолетнего опада, но самые высокие показатели в соотношении живых и мертвых растительных остатков дает подстилка. На контрольном участке величина подстилки на 2015-2016 года исследований была стабильна (9,2-11,2 ц/га), резко снижаясь в 2017 году до 7,5 ц/га - 33\%. На участке №3 её показатели в 2017 г. возросли почти в 2 раза с 4.4 до 8 ц/га, что свидетельствует о меняющемся термическом режиме не только приземных слоев воздуха и поверхностных горизонтов почвы, но происходят изменения в водном и питательном режимах. В результате этих 
процессов наблюдаются сдвиги в флористическом составе и структуре травостоя, резко активизируются демутационные процессы.

\section{Bblвodbl}

Анализ биоморфологического состава, структуры и продуктивности фитоценозов пробных площадей поймы реки Зуя отражает типичные особенности сложения лугов. Выявление изменений в особенностях сложения и продукционно-деструкционного процесса с учетом антропогенных факторов а растительных сообществ в сравнительном аспекте дают возможность спрогнозировать происходящие в фитоценозах изменения, а так же могут послужить основой для их дальнейшего многолетнего мониторинга.

\section{Сиисок литературы}

1. Агрокліматичний довідник по Автономній Республіці Крим (1986-2005 pp.): Довідкове видання / За ред. О.I. Прудко, Т.I. Адаменко. - ЦГМ в АРК. - Симферополь: Таврида, 2011. - 343 с.

2. Андреев Н.Г. Луговедение / Н.Г. Андреев. - М.: Агропроимиздат, 1985. -255 c.

3. Буданцев А.Л. Ресурсоведение лекарственных растений / А.Л. Буданцев, И.П. Хоритонова. - СПб.: СбГУ, 1999. - 56 с.

4. Бузук Г.Н. Оптимизация метода оценки обилия и площади зарослей лекарственных растений / Г.Н. Бузук, О.В. Созинов // Растительные ресурсы. - 2014. - Т. 50. - №2. - С. 316-323.

5. Голубев В.Н. Биологическая флора Крыма / В.Н. Голубев. - Ялта: НБСННЦ, 1996. - 126 с.

6. Кобечинская В.Г. Динамика горизонтальной структуры пойменной растительности на заповедных территориях Крыма / В.Г. Кобечинская // Ученые записки. - 2016. - С. 56-67.

7. Рубцова Н.И. Определитель высших растений Крыма. - Наука, 1972. $555 \mathrm{c}$. 


\section{References}

1. Prudko, O. I., \& Adamenko, T. I. (2011). Agroklimatichnii dovidnik po Avtonomnii Respublitsi Krim (1986-2005 rr.): Dovidkove vidannia., 343. Simferopol': Tavrida.

2. Andreev, N. G. (1985). Lugovedenie. M.: Agroproimizdat.

3. Budantsev, A. L., \& Khoritonova, I. P. (1999). Resursovedenie lekarstvennykh rastenii. $\mathrm{SPb}$.: $\mathrm{SbGU}$.

4. Buzuk, G. N., \& Sozinov, O. V. (2014). Optimizatsiia metoda otsenki obiliia i ploshchadi zaroslei lekarstvennykh rastenii. Rastitel'nye resursy, T.50, 2, 316-323.

5. Golubev, V. N. (1996). Biologicheskaia flora Kryma. Ialta: NBS-NNTs.

6. Kobechinskaia, V. G. (2016). Dinamika gorizontal'noi struktury poimennoi rastitel'nosti na zapovednykh territoriiakh Kryma. Uchenye zapiski, S. 56.

7. Rubtsova, N. I. (1972). Opredelitel' vysshikh rastenii Kryma., 555. Nauka.

Кобечинская Валентина Григорьевна - канд. биол. наук, доцент ФГАОУ ВО «Крымский федеральный университет им. В.И. Вернадского», Россия, Симферополь.

Kobechinskaya Valentina Grigor'evna - candidate of biological sciences, associate professor at the V.I. Vernadsky Crimean Federal University, Russia, Simferopol.

Аджикелямова Найле Алядиновна - магистрант ФГАОУ ВО «Крымский федеральный университет им. В.И. Вернадского», Россия, Симферополь.

Adzhikelyamova Najle Alyadinovna - graduate student at the V.I. Vernadsky Crimean Federal University, Russia, Simferopol.

Аблаев Расим Сетмерович - магистрант ФГАОУ ВО «Крымский федеральный университет им. В.И. Вернадского», Россия, Симферополь.

Ablaev Rasim Setmerovich - graduate student at the V.I. Vernadsky Crimean Federal University, Russia, Simferopol. 